\title{
Імунний статус у хворих на цукровий діабет із синдромом діабетичної стопи
}

\begin{abstract}
У статті наведено результати обстеження 32 хворих на цукровий діабет із синдромом діабетичної стопи. Отримані результати свідчать про втягнення імунної системи в процес запалення і можуть бути відображенням процесів масивного гнійнонекротичного запалення з втягненням у патологічний процес автоімунних механізмів.
\end{abstract}

Ключові слова: імунний статус; цукровий діабет; діабетична стопа.

Лікування цукрового діабету (ЦД) і його хірургічних ускладнень $є$ однією з найактуальнішіх проблем сучасної медицини. На думку експертів International Diabetes Federation, при збереженні такого швидкого темпу поширення ЦД та відсутності адекватних засобів боротьби з його ускладненнями, витрати на лікування таких хворих скоро перевищуватимуть доходи від економічного росту всіх країн світу [1]. Одним із найбільш частих та тяжких ускладнень ЦД є синдром діабетичної стопи (СДС), який являє собою специфічний симптомокомплекс ураження стоп, основою патогенезу якого є діабетичні мікро-, макроангіопатії, периферична нейропатія нижніх кінцівок та остеоартропатія. Ці процеси розвиваються паралельно, взаємно обтяжуючи один одне, з приєднанням тяжких гнійно-некротичних уражень, які характеризуються особливим складом мікрофлори і перебігають на тлі глибоких обмінних порушень та імуносупресії. Цей синдром ускладнює перебіг ЦД майже у 25 \% пацієнтів. Ризик виникнення гангрени нижніх кінцівок у них у 20 разів вищий, ніж у загальній популяції [2, 3 ]. Розвиток сучасної медицини, удосконалення методів інструментального дослідження та хірургічного лікування СДС дозволяють сьогодні говорити про якісно новий етап надання допомоги пацієнтам на пізніх стадіях процесу, проте все ж таки багато питань методологічного підходу до лікування потребують додаткового вивчення. Це стосується, насамперед, особливостей імунного статусу хворих при СДС, оскільки окремі аспекти патогенезу, зокрема, питання імунної відповіді, недостатньо вивчені $[4,5]$.

Мета роботи: вивчити окремі імунні показники у хворих на ЦД з СДС.

У наших дослідженнях було використано кров 32 хворих на ЦД з гнійно-некротичними ураженнями стопи - дослідна група та кров 26 донорів - порівняльна група. Відповідно до патології хворі дослідної групи розділилися черговим чином: волога гангрена стопи - 5 (19,3 \%) хворих, флегмона стопи 14 (53,8 \%) хворих, діабетична остеоартропатія з флегмоною - 7 (26,9%). Для дослідження використовували венозну кров, оброблену гепарином із метою визначення гематологічних показників (гемоглобін, кількість еритроцитів), таких імунологічних показників, як кількість лейкоцитів, тромбоцитів, кількість Т-, В-лімфоцитів, функціональної активності фагоцитуючих лейкоцитів, підрахунок лейкоцитарної формули, швидкість осідання еритроцитів. Друга частина крові використовувалася з метою отримання сироватки крові для визначення вмісту циркулюючих імунних комплексів (ЦІК), імуноглобулінів класів М, A, G, білків гострої фази запального процесу (СРБ), активності системи комплементу.

Визначення кількості Т-лімфоцитів у периферичній крові людини виконували методом спонтанного розеткоутворення (Е-РУК), які утворюють розетки з еритроцитами барана, субпопуляцію незрілих В-лімфоцитів, які реагують з еритроцитами миші (Ем-РУК). ЦІК визначали шляхом преципітації в 3,75 \% поліетиленгліколі 6000 з подальшим фотометричним вимірюванням оптичної щільності преципітату. Імуноглобуліни класів A, M, G в сироватці крові визначали способом Манчіні, великі грануломісткі лімфоцити (ВГЛ) в крові визначали в мазках пофарбованих азур-еозином.

Гемолітичну активність системи комплементу оцінювали за 100 \% лізисом еритроцитів барана сенсибілізованими крілячими антитілами. Вміст білків гострої фази запального процесу визначали якісно за реакцією преципітації в анти-СРБсироватці.

Фагоцитарну активність нейтрофілів визначали за їх здатності захоплювати мікробні тіла вби- 
тої культури St. Aureus, здатності до внутрішньоклітинної продукції активних форм кисню спонтанно та після інкубації із St. Aureus (HCT сп. та НСТ інк.). Різницю НСТ інк. та НСТ сп. оцінювали як функціональний резерв окисно-відновного потенціалу (НСТ рез.)

Статистичну обробку отриманих результатів проводили за загальноприйнятою методикою 3 визначенням критерію Стьюдента. Різницю показників вважали достовірною при р <0,05. В таблиці 1 наведено результати гематологічних досліджень.

За даними таблиці 2, відсотковий та абсолютний вміст Е-РУК (Т-лімф) та Ем-РУК (В-лімф) в обох групах суттєво не різняться. Привертає увагу значне підвищення вмісту малодиференційованих незрілих аутореактивних Т-лімфоцитів (аутоРук) з (6,2 \pm 0,8 до 13,4 \pm 1,6 \%; $\mathrm{p}<0,001,120 \pm 20$ до 270 4 40; $\mathrm{p}<0,001)$.

Таблиця 1. Результати гематологічних досліджень (N-32, n-26)

\begin{tabular}{|c|c|c|c|c|c|c|c|}
\hline \multirow{3}{*}{ Групи хворих } & \multicolumn{7}{|c|}{ Гематологічні дослідження } \\
\hline & \multirow{2}{*}{$\mathrm{Hb}$ г/л } & \multirow{2}{*}{ Ер. $10 * 6 /$ мкл } & \multirow{2}{*}{ Тр. 10*3/мкл } & \multirow{2}{*}{ ШОЕ. мм/год } & \multirow{2}{*}{ Лейк. $10 * 9$} & \multicolumn{2}{|c|}{ Нейтрофіли } \\
\hline & & & & & & $\%$ & /МКЛ \\
\hline 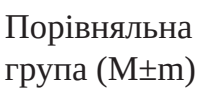 & $139 \pm 3$ & $4,1 \pm 0,1$ & $200 \pm 10$ & $4,7 \pm 0,4$ & $5800 \pm 210$ & $55 \pm 3,0$ & $3170 \pm 690$ \\
\hline $\mathrm{n}$ & 20 & 20 & 20 & 20 & 20 & 20 & 20 \\
\hline 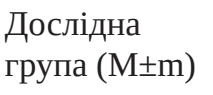 & $105 \pm 7$ & $3,0 \pm 0,1$ & $210 \pm 14$ & $49,2 \pm 2,99$ & $\begin{array}{c}10900 \pm \\
750\end{array}$ & $73,3 \pm 2,6$ & $8130 \pm 690$ \\
\hline $\mathrm{n}$ & 20 & 20 & 20 & 20 & 20 & 20 & 20 \\
\hline $\mathrm{p}$ & $<0,001$ & $<0,001$ & $<0,001$ & $<0,001$ & $<0,001$ & $<0,001$ & $<0,001$ \\
\hline
\end{tabular}

Продовження табл. 1

\begin{tabular}{|c|c|c|c|c|c|c|c|c|}
\hline \multirow{3}{*}{ Групи хворих } & \multicolumn{8}{|c|}{ Гематологічні дослідження } \\
\hline & \multicolumn{2}{|c|}{ Базофіли } & \multicolumn{2}{|c|}{ П/ядерні } & \multicolumn{2}{|c|}{ С/ядерні } & \multicolumn{2}{|c|}{ Еозинофіли } \\
\hline & $\%$ & /МКЛ & $\%$ & /МКЛ & $\%$ & /МКЛ & $\%$ & /МКЛ \\
\hline $\begin{array}{l}\text { Порівняльна група } \\
(\mathrm{M}+/-\mathrm{m})\end{array}$ & $0,3 \pm 1$ & 20 & $3,6 \pm 0,4$ & 200 & $54,8 \pm 2,2$ & 2980 & $1,7 \pm 0,3$ & 130 \\
\hline $\mathrm{n}$ & 20 & 20 & 20 & 20 & 20 & 20 & 20 & 20 \\
\hline $\begin{array}{l}\text { Дослідна група } \\
\text { (M+/-m) }\end{array}$ & $0,4 \pm 0,2$ & $31,6 \pm 10$ & $3,7 \pm 1,3$ & $440 \pm 180$ & $69,5 \pm 2,6$ & $7670 \pm 620$ & $1,9 \pm 0,3$ & $190 \pm 40$ \\
\hline $\mathrm{n}$ & 19 & 19 & 20 & 20 & 20 & 20 & 20 & 20 \\
\hline $\mathrm{p}$ & $<0,001$ & $<0,001$ & & & $<0,001$ & $<0,001$ & & \\
\hline
\end{tabular}

Продовження табл. 1

\begin{tabular}{|c|c|c|c|c|c|c|c|c|}
\hline \multirow{3}{*}{ Групи хворих } & \multicolumn{8}{|c|}{ Гематологічні дослідження } \\
\hline & \multicolumn{2}{|c|}{ Моноцити } & \multicolumn{2}{|c|}{ Лімфоцити } & \multicolumn{2}{|c|}{ БГЛ } & \multicolumn{2}{|c|}{ Плазмоцити } \\
\hline & $\%$ & /МкЛ & $\%$ & /МКЛ & $\%$ & /МКЛ & $\%$ & /МКЛ \\
\hline $\begin{array}{l}\text { Порівняльна група } \\
(\mathrm{M}+/-\mathrm{m})\end{array}$ & $4,7 \pm 0,5$ & 340 & $33,5 \pm 2,5$ & $1960 \pm 160$ & $1,8 \pm 0,3$ & $100 \pm 20$ & $0,1 \pm 0,1$ & 3 \\
\hline $\mathrm{n}$ & 20 & 20 & 20 & 20 & 20 & 20 & 120 & 20 \\
\hline $\begin{array}{l}\text { Дослідна група } \\
(\mathrm{M}+/-\mathrm{m})\end{array}$ & $4,4 \pm 0,4$ & $480 \pm 500$ & $20,6 \pm 2,7$ & $1910 \pm 160$ & $0,5 \pm 0,2$ & $40 \pm 21$ & $0,3 \pm 0,1$ & $30 \pm 10$ \\
\hline $\mathrm{n}$ & 19 & 19 & 19 & 19 & 19 & 1 & 19 & 19 \\
\hline $\mathrm{p}$ & & & $<0,001$ & $<0,001$ & & & & \\
\hline
\end{tabular}


Таблиця 2. Процентний та абсолютний вміст Е-РУК (Т-лімф) та Ем-РУК (В-лімф) (N-32, n-26)

\begin{tabular}{||c|c|c|c|c|c|c|c||}
\hline \multirow{2}{*}{ Групи хворих } & \multicolumn{3}{|c|}{ Е-РУК } & \multicolumn{2}{c|}{ Ауто-РУК } & \multicolumn{3}{c||}{ Ем-РУК } \\
\cline { 2 - 9 } & Акт\% & Тот\% & /мкл & $\%$ & /мкл & $\%$ & /мкл \\
\hline $\begin{array}{l}\text { Порівняльна група } \\
(\mathrm{M} \pm \mathrm{m})\end{array}$ & $58,4 \pm 2,7$ & $68,3 \pm 2,1$ & $1350 \pm 130$ & $6,2 \pm 0,8$ & $120 \pm 20$ & $6,2 \pm 0,8$ & $130 \pm 30$ \\
\hline $\mathrm{n}$ & 20 & 20 & 20 & 20 & 20 & 20 & 20 \\
\hline $\begin{array}{c}\text { Дослідна група } \\
(\mathrm{M} \pm \mathrm{m})\end{array}$ & $61 \pm 2,4$ & $72,8 \pm 2,2$ & $1380 \pm 140$ & $13,4 \pm 1,6$ & $270 \pm 40$ & $5,4 \pm 0,9$ & $100 \pm 20$ \\
\hline $\mathrm{n}$ & 19 & 19 & 19 & 19 & 19 & 19 & 19 \\
\hline $\mathrm{p}$ & & & & $<0,001$ & $<0,001$ & & \\
\hline \hline
\end{tabular}

Дані таблиці 3 показують, що у хворих із СДС підвищується рівень імуноглобулінів класів А (з 2,18 \pm 0,18 до 4,18 \pm 0,4 г/л; $\mathrm{p}<0,001), \mathrm{G}$ (з 14,6 \pm $0,7$ до 20,8 $\pm 1,2$ г/л; $\mathrm{p}<0,001), \mathrm{M}$ (з 1,34 \pm 0,12 до $2,09 \pm 0,2$ г/л; $\mathbf{p}<0,001)$. При цьому найбільш суттєві зміни спостерігаються відносно імуноглобу- ліну А, вміст яких збільшується у хворих із СДС в середньому в два рази, а в окремих випадках в 3-4 рази порівняно з порівняльною групою.

Вивчення ЦІК показало значне підвищення цього показника у хворих дослідної групи (з 31士 3 до $87 \pm 6$ одиниць оптичної щільності; $\mathrm{p}<0,001)$,

Таблиця 3. Вміст імуноглобулінів, циркулюючих імунних комплексів, показники системи комплементу в порівняльній та дослідній групах (N-32, n-26)

\begin{tabular}{|c|c|c|c|c|c|c|}
\hline \multirow{2}{*}{ Групи хворих } & \multicolumn{3}{|c|}{ Е-РУК } & \multirow{2}{*}{$\begin{array}{l}\text { ЦІК од. опт. } \\
\text { щіл. }\end{array}$} & \multirow{2}{*}{$\begin{array}{c}\text { С-ма компл. } \\
\text { мл. }\end{array}$} & \multirow{2}{*}{ СРБ } \\
\hline & А г/л & $\mathrm{M} \mathrm{г/л}$ & G г/л & & & \\
\hline $\begin{array}{l}\text { Порівняльна група } \\
(\mathrm{M} \pm \mathrm{m})\end{array}$ & $2,18 \pm 0,18$ & $1,34 \pm 0,12$ & $14,6 \pm 0,7$ & $31 \pm 3$ & $0,039 \pm 0,003$ & - \\
\hline $\mathrm{n}$ & 20 & 20 & 20 & 20 & 20 & 20 \\
\hline $\begin{array}{l}\text { Дослідна група } \\
(\mathrm{M} \pm \mathrm{m})\end{array}$ & $4,18 \pm 0,4$ & $2,09 \pm 0,2$ & $20,8 \pm 1,2$ & $87 \pm 6$ & $0,026 \pm 0,005$ & $62 \%$ \\
\hline $\mathrm{n}$ & 19 & 19 & 19 & 19 & 19 & 13 \\
\hline $\mathrm{p}$ & $<0,001$ & $<0,001$ & $<0,001$ & $<0,001$ & $<0,05$ & \\
\hline
\end{tabular}

що свідчить про наявність у них антигенів та антитіл, включно власні, які формують імунні комплекси. Це також підтверджують дані, отримані при вивченні гемолітичної активності компліменту. При цьому активність компліменту достовірно підвищується у хворих з СРБ (з 0,039 \pm 0,003 до 0,026 \pm 0,005 гем. од/мл; p<0,05) в зв’язку з її активацією класичним шляхом - надлишковим вмістом ЦІК. 3 даних, наведених в таблиці 4, видно, що в 62 \% хворих дослідної групи реєструється позитивна реакція на СРБ, що може бути наслідком збільшення концентрації прозапальних цитокінів при СДС.

У таблиці 4 наведено дані вивчення фагоцитарної активності нейтрофілів.
За результатами таблиці 4 не виявлено суттєвої різниці в поглинальній активності фагоцитуючих лейкоцитів - здатності захоплювати мікробні тіла у пацієнтів дослідної та порівняльної груп. Але у хворих дослідної групи суттєво підвищена спонтанна активність нейтрофілів синтезувати активні форми кисню (НСТ сп.) - (9 \pm 2$)$ \% у здорових людей та $(17 \pm 3)$ \% у хворих із СДС, що свідчить про приєднання вторинної бактеріальної інфекції і в зв’язку з цим підвищення антигенного навантаження.

Таким чином, результати свідчать про втягнення імунної системи в процес запалення і можуть бути відображенням процесів масивного не- 
Таблиця 4. Фагоцитарна активність нейтрофілів (N-32, n-26)

\begin{tabular}{|c|c|c|c|c|}
\hline \multirow{2}{*}{ Групи хворих } & \multicolumn{3}{|c|}{ НСТ тест } & \multirow{2}{*}{$\mathrm{F} \%$} \\
\hline & НСТ сп.\% & НСТ інк.\% & НСТ рез.\% & \\
\hline Порівняльна група (M × m) & $9 \pm 2$ & $36 \pm 9$ & $21 \pm 7$ & $65 \pm 5$ \\
\hline $\mathrm{n}$ & 20 & 20 & 20 & 20 \\
\hline Дослідна група (M × m) & $17 \pm 3$ & $37 \pm 3$ & $19 \pm 2$ & $69 \pm 2$ \\
\hline $\mathrm{n}$ & 15 & 15 & 15 & 19 \\
\hline $\mathrm{p}$ & $<0,05$ & $<0,001$ & $<0,001$ & $<0,001$ \\
\hline
\end{tabular}

кротичного розпаду тканин із задіянням автоімунних механізмів. Характер перебігу та кінцевий результат патології при СДС залежить від стану імунної системи у цих хворих.

\section{СПИСОК ЛІТЕРАТУРИ}

1. Surviving sepsis campaing: international guidelines for management of severe sepsis and septic shock: 2012 / R. P. Dellinger, M. M. Levy, A. Rhodes [et al.] // Crit. Care Med. - 2013. - Vol 41, No. 2. - P. 580-637.

2. Стандарти діагностики та лікування ендокринологічних захворювань / За ред. М. Д. Тронька. - К. : ТОВ «Доктор-Медіа», 2007. - 352 c.

3. Шлапак I. П. Цукровий діабет: погляд з позиції лікаря-

\section{REFERENCE}

1. Dellinger, R.P., Levy, M.M., \& Rhodes, A. (2013). Surviving sepsis campaing: international guidelines for management of severe sepsis and septic shock: 2012. Crit. Care Med., 41 (2), 580-637.

2. Tronko, M.D. (Ed.). Standarty diahnostyky ta likuvannia endokrynolohichnykh zakhvoriuvan [Standards of diagnostics and treatment of endocrinolone diseases]. Kyiv: TOV "Doktor-Media" [in Ukrainian].

3. Shlapak, I.P. \& Halushko, O.A. (2010). Tsukrovyi diabet: pohliad z pozytsii likaria-anestezioloha [Diabetes mellitus: a view from the standpoint of an anesthesiologist]. Kyiv: Knyha- анестезіолога: навч. посіб. / І. П. Шлапак, О. А. Галушко. К. : Книга-плюс, 2010. - 160 с.

4. Савон И. Л. Коррекция иммунных нарушений у больных сахарным диабетом II типа с осложненным синдромом диабетической стопы / И. Л. Савон // Клін. хірургія. - 2011. № 8. - C. 55-58.

5. Стан клітинного імунітету при синдромі діабетичної стопи / О. Й. Хомко, Р. І. Сидорчук, П. В. Волянюк [та ін.]. // Клінічна хірургія. - 2017. - № 8. - С. 48-49.

plius [in Ukrainian].

4. Savon, Y.L. (2011). Korrektsiya immunnykh narusheniy u bolnykh sakharnym diabetom II tipa s oslozhnennym sindromom diabeticheskoy stopy [Correction of immune disorders in patients with type II diabetes mellitus with complicated diabetic]. Klin. khirurhiia - Clinical Surgery, 8, 55-58 [in Russian].

5. Khomko, O.Y., Sydorchuk, R.I., Volianiuk, P.V., Karliichuk, O.Ya., Petriuk, B. V., Bilyk, I.I., \& Knut, R.P (2017) Stan klitynnoho imunitetu pry syndromi diabetychnoi stopy [The state of cellular immunity in diabetic foot syndrome]. Klin. khirurhiia - Clinical Surgery, 8, 48-49 [in Ukrainian].

Отримано 14.05.2020

Електронна адреса для листування: antoniv.vasyl@gmail.com

M. M. STETS, V. R. ANTONIV, Y. P. TCYURA, S. L. KINDZER, V. M. PEREPADYA

O. Bohomolets National Medical University, Kyiv

\title{
IMMUNE STATUS IN PATIENTS WITH DIABETES MELLITUS WITH DIABETIC FOOT SYNDROME
}

\begin{abstract}
The article presents the results of a survey of 32 patients with diabetes with diabetic foot syndrome. The results obtained indicate the involvement of the immune system in the inflammation process and can be a reflection of the processes of massive purulent necrotic inflammation with involvement in the pathological process of autoimmune mechanisms.
\end{abstract}

Key words: immune status; diabetes; diabetic foot. 
Н. М. СТЕЦЬ, Ю. П. ЦЮРА, В. Р. АНТОНИВ, С. Л. КИНДЗЕР, В. Н. ПЕРЕПАДЯ

Национальный медицинский университет имени А. А. Богомольца, Киев

ИМУННЫЙ СТАТУС У БОЛЬНЫХ САХАРНЫМ ДИАБЕТОМ С СИНДРОМОМ ДИАБЕТИЧЕСКОЙ

\section{СТОПЫЫ}

В статье представлены результаты обследования 32 больных сахарным диабетом с синдромом диабетической стопы. Полученные результаты свидетельствуют о вовлечении иммунной системы в процесс воспаления и могут быть отражением процессов массивного гнойно-некротического воспаления с вовлечением в патологический процесс аутоиммунных механизмов.

Ключевые слова: имунный статус; сахарный диабет; диабетическая стопа. 